\title{
Methodological Approaches to Measuring Intercultural Competence: A Case Study of the SAGE Database
}

\author{
Dalia PRAKAPIENÉ ${ }^{1}$, Romas PRAKAPAS ${ }^{2}$ \\ ${ }^{1}$ Department of Management, General Jonas Žemaitis Military Academy of Lithuania, Šilo g. 5A, LT-10322, Vilnius \\ ${ }^{2}$ Institute of Educational Sciences and Social Work, Mykolas Romeris University, Ateities 20, LT-08303, Vilnius
}

E-mails: ${ }^{1}$ dalia.prakapiene@lka.lt; ${ }^{2}$ prakapas@mruni.eu;

\begin{abstract}
The article analysed methodological scales for measuring intercultural competence. Taking into account the ones presented in scientific literature, SAGE's scientific publications database was selected as the data collection source. Methodologically validated scales were evaluated from the perspective of management science in order to select the most used ones oriented to management research. Therefore, four most popular measurement scales that have received the most attention in different countries were distinguished. The article also ranked the most popular scientific journals in terms of research on the above mentioned competencies using said methodological scales as well as explored military intercultural competence to determine the possibilities of using methodological scales.
\end{abstract}

KEY WORDS: intercultural competence; intercultural competence in military, measurement scale; SAGE database

\section{Introduction}

Intercultural competence in terms of scientific cognition is unique due to its versatility, i.e. it combines several separate components such as culture and competence. Despite the fact that different scientific fields present different views on the concept of culture, it is generally understood as an indicator of the individual's maturity, the realization of his or her creative and spiritual powers as well as the totality of social achievements, valued in all spheres of life. Thus, culture, human general competencies and experience are interlinked. The term intercultural competence is often used in scientific literature to link it with knowledge and understanding of local, national, regional, European and global cultures and their expressions, including language, heritage, traditions and specific cultural products. Prakapienė [20] points out that intercultural competence manifests itself in the most diverse areas of modern society. For instance, in economy, intercultural competence is inherent in the development of global markets and the ability to communicate while labour integration is taking place not only in the EU but also in other parts of the world. In the social field, however, intercultural competence is demonstrated through migration processes, assimilation, the creation of mixed families, work in multinational companies and teams. Both intercultural mobility that can be detected in the field of professional development and training (exchange programs, exchange of professionals, etc.) and the unity of human rights, democracy and law are also achieved through that competence.

The importance of intercultural competence is also highlighted in the military field. The Military Strategy of the Republic of Lithuania [13] states that Lithuania, as a member of NATO and the European Union, has a responsibility to also ensure the security and stability of the Euro-Atlantic area. That is to say the Lithuanian Armed Forces are required to be ready, together with their allies, to respond to emerging international security challenges. Therefore, open door policies, the development of cooperation with other international organizations and partner countries as well as the enhancement of Euro-Atlantic and international security through various types of international operations are of utmost importance for the Alliance. In this context, the Lithuanian Armed Forces are required not only to be able to act independently, respond rapidly to threats, prepare for wide-range operations, lead and manage effectively, etc., but also to develop intercultural competencies such as the ability to work with NATO Allied Powers, interact with both military officers and civilians in international operations, etc.

In scientific literature $[5 ; 6 ; 14 ; 15 ; 16 ; 19 ; 21 ; 22$ et al.] different models of intercultural competence analysis can be found that distinguish different components of intercultural competence assessment (e.g., openness, dedication/commitment, emotion regulation/management, empathy, ability to interpret, compare, analyse and evaluate, ability to listen and hear the interlocutor's opinion, ability to build sustainable intercultural relationships, adaptability, ability to handle/manage/avoid conflicts, ability to observe, ability to lead people in intercultural

\footnotetext{
${ }^{1}$ Corresponding author.

E-mail address: dalia.prakapiene@lka.lt.
} 
contexts, cultural knowledge, cultural awareness, flexibility, understanding of a non-verbal language, willingness to participate, respect/sensitivity to another culture, practicality, self-esteem, curiosity and willingness to discover, learn, tolerance for uncertainty, foreign language skills, efficiency). Since 1975 more than 30 scales for the assessment of intercultural competence have been developed, validated and presented in scientific literature.

Research problem. Given that intercultural competence covers a wide range of fields, it raises a question of how useful the developed scales are for the management science, how often and which ones are used in management research.

Research object is the measurement scales for intercultural competence research.

Research aim is to analyse scientific preferences with regard to scales for the assessment of intercultural competencies in scientific publications on management.

\section{Research Method}

The research was carried out using the method of systematic literature review, which, according to Pittaway [18], is for making sense of large volumes of information. The chosen research objective focused on managing large amounts of information in an attempt to find answers to one or another question. Another feature of the method that led to choosing it is that it enables the situation to be assessed by distinguishing opportunities and threats. The selected SAGE database of research articles is a leading independent, academic and professional publisher of innovative, high-quality content, known to the scientific world since 1965 and has published over 1,000 scientific publications (https://uk.sagepub.com/en-gb/eur/home). Also, said database, besides publishing and citing scientific articles, pays much attention to methodology and presentation of research methods. Considering the instruments presented in scientific literature to study intercultural competence [17], publications from 2010 to 2020, which analysed the research data collected and studied using the aforementioned measurement scales, were reviewed in the SAGE database. They were selected by publication titles and abstracts, using the data filtering and sorting tools. Out of the total data set, only those publications that had the word management as the subject and met the criteria of relevance in addition to being published within the specified period were selected for deeper analysis.

\section{Research Results}

The scientific research instrument scales used to measure intercultural competence have been analysed in scientific literature since the 1970s. One of the first published scales is Cross-Cultural Interaction Inventory (CCII) by Yellen \& Mumford [17] published in 1975. More active research into intercultural competence began a decade later when Personal Communication Worldview Scale was developed and validated [7]. It is noteworthy that this scale has not lost its relevance. Out of different scales (see Table 1) described in methodological literature [17] for measuring intercultural competence, in the last decade this scale has been used 1,773 times, of which data from 45 research have been published in publications on the management science (SAGE database).

Table 1.

Changes in Scientific Preferences for Scales Used to Measure Intercultural Competence

\begin{tabular}{|l|c|c|c|}
\hline \multirow{2}{*}{ Scale } & $\begin{array}{c}\text { First description of } \\
\text { the scale in } \\
\text { scientific literature }\end{array}$ & $\begin{array}{c}\text { Number of scientific articles related to the } \\
\text { given scale (2010-2020) }\end{array}$ \\
\cline { 3 - 4 } & 1975 & 2 & Management \\
\hline $\begin{array}{l}\text { Cross-Cultural Interaction Inventory } \\
\text { (CCII) }\end{array}$ & 1975 & 9 & - \\
\hline Culture Shock Inventory (CSI) & 1987 & 1773 & 1 \\
\hline $\begin{array}{l}\text { Personal Communication Worldview } \\
\text { Scale }\end{array}$ & 1992 & 5 & 19 \\
\hline $\begin{array}{l}\text { Cross-Cultural Adaptability Inventory } \\
\text { (CCAI) }\end{array}$ & 1992 & 492 & 19 \\
\hline $\begin{array}{l}\text { Cross-Cultural World Mindedness Scale } \\
\text { (CCWMS) }\end{array}$ & 1992 & 296 & 2 \\
\hline $\begin{array}{l}\text { Intercultural Communication Inventory } \\
\text { (ICI) }\end{array}$ & 1992 & 2 & \\
\hline Intercultural Sensitivity Inventory (ICSI) & & 5 & 19 \\
\hline
\end{tabular}




\begin{tabular}{|c|c|c|c|}
\hline Cross-Cultural Sensitivity Scale (CCSS) & 1993 & 18 & \\
\hline Global Mindedness Scale & 1993 & 662 & 24 \\
\hline Overseas Assignment Inventory (OAI) & 1994 & 1 & 1 \\
\hline $\begin{array}{l}\text { E-model Scale for Intercultural Effective- } \\
\text { ness }\end{array}$ & 1995 & 1261 & 76 \\
\hline Prospector & 1997 & 56 & 10 \\
\hline Global Awareness Profile (GAPtest) & 1998 & 3383 & 167 \\
\hline Sociocultural Adaptation Scale (SCAS) & 1999 & 15 & 1 \\
\hline $\begin{array}{l}\text { Attitudinal \& Behavioral Openness Scale } \\
\text { (ABOS) }\end{array}$ & 2000 & 2 & - \\
\hline Intercultural Sensitivity Scale (ISS) & 2000 & 1011 & 54 \\
\hline $\begin{array}{l}\text { Multicultural Personality Questionnaire } \\
\text { (MPQ) }\end{array}$ & 2000 & 2 & 2 \\
\hline $\begin{array}{l}\text { Intercultural Adjustment Potential Scale } \\
\text { (ICAPS) }\end{array}$ & 2001 & 3 & 3 \\
\hline Intercultural Readiness Check (IRC) & 2001 & 2 & 1 \\
\hline $\begin{array}{l}\text { Cross-Cultural Adaptability Scale } \\
\text { (CCAS) }\end{array}$ & 2002 & 2 & - \\
\hline Cultural Intelligence Scale (CQS) & 2003 & 15 & 7 \\
\hline $\begin{array}{l}\text { Intercultural Development Inventory } \\
\text { (IDI) }\end{array}$ & 2003 & 22 & 1 \\
\hline Scale of Ethnocultural Empathy (SEE) & 2003 & 41 & \\
\hline $\begin{array}{l}\text { Global Leadership Life Inventory } \\
\text { (GlobeInvent) }\end{array}$ & 2004 & 1 & 1 \\
\hline $\begin{array}{l}\text { Monroe Multicultural Attitude Scale } \\
\text { (MASQUE) }\end{array}$ & 2006 & 24 & - \\
\hline $\begin{array}{l}\text { Intercultural Readiness Assessment } \\
\text { (IRA) }\end{array}$ & 2007 & 4 & - \\
\hline Big Five Inventory (BFI) & 2008 & 235 & 4 \\
\hline $\begin{array}{l}\text { Cross-Cultural Competence Inventory } \\
\text { (CCCI) }\end{array}$ & 2009 & 6 & - \\
\hline
\end{tabular}

Source: SAGE

Research data showed that out of the extremely high volume of scientific publications (over 9,000 units) published between 2010 and 2020, only about 400 of them can be linked to the management science. This shows that intercultural competence is relevant to not only management science, but also psychology and communication. Based on keywords and references to specific scientific fields and disciplines, intercultural communication is analysed using the aforementioned scales in medical, educational, theological, economic and other publications. However, taking the research objective into account, more attention was paid to publications on the management science.

In addition to Personal Communication Worldview Scale [7], E-model Scale for Intercultural Effectiveness [12], Global Awareness Profile (GAPtest) [4] and Intercultural Sensitivity Scale (ISS) [3] are also frequently used to study intercultural competence from the perspective of management science. It is these scales that are most used to carry out different studies that are later published in different scientific journals around the world. These publications were ranked by the percentage of published articles that used the four scales:

1. International Journal of Cross Cultural Management

2. Global Business Review

3-4. Public Relations Inquiry

3-4. Tourism and Hospitality Research

5-7. Advances in Developing Human Resources

5-7. Leadership

5-7. Recherche et Applications en Marketing 
8-10. Management and Labour Studies

8-10. The Journal of Business Communication

8-10. Vikalpa

11. Business Perspectives and Research

12. Action Research

13-14. Human Resource Development Review

13-14. South Asian Journal of Human Resources Management

15. Asia-Pacific Journal of Management Research and Innovation

Analysing managerial scientific articles in the SAGE database that were written using validated intercultural competence research scales, it was noted that in the last decade the least attention to intercultural competence research was paid in 2011 (4.90\%), followed by a steady increase in the number of studies, reaching a peak in 2016 (17.48\%). The number of publications has slightly decreased in recent years (see Fig.1.).

Taking into account studies published in 2018 and 2019, E-model Scale for Intercultural Effectiveness [12] and Personal Communication Worldview Scale [7] were found to be extremely popular in the context of all other research scales. One of the dominant publications in the said period was International Journal of Cross Cultural Management, which published the most scientific articles on management related to the research scales in question.

The research also sought to determine how the military aspect is reflected in the management research context. It should be noted that no direct research on security or the military field, using search criteria for specific scales, was found. However, after changing search terms and reading the research methodology in addition to the title and the summary of the publications, the use of some of the scales was detected. Therefore, methodological scales are used in the military sector and have been acknowledged by various scientists [2; 9; 23]. Individual authors, using different scales, have evaluated the expression of troops' or officers' intercultural competence in various areas. Abbe et al. [1], for example, assessed intercultural competencies of US serving troops and cadets using three key research instruments: the Cultural Intelligence Scale (CQS), the Multicultural Personality Questionnaire (MPQ) and the Intercultural Development Inventory (IDI). The purpose of this study was to test whether research instruments designed for nonmilitary purposes could be used effectively in the military sector. Its results showed great convergence and relevance of the three instruments in the context of military research. However, after considering the purpose of the research instruments, peculiarities of the research field and preconditions for their creation, the Cross-Cultural Assessment Tool and Cross-Cultural Competence Inventory, which were not adapted but rather specifically designed to analyse military intercultural competencies, are thought to be superior. Although there are few examples of the application of these scales in the publications referenced in the SAGE database and scientific publications on management are dominated by those listed in Table 1, specialized research and specialized research scales should be used to carry out management research in the military field.

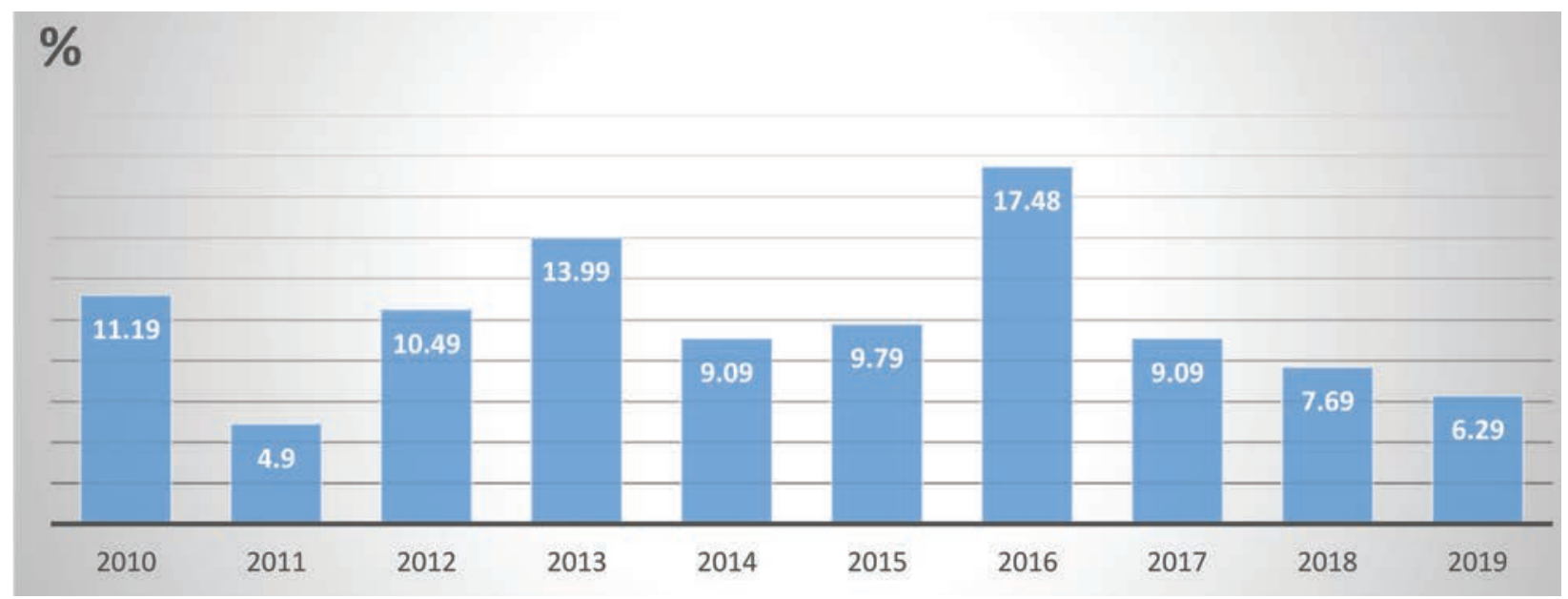

Fig. 1. Percentage Change in the Number of Managerial Publications and Studies that Used Scales Described in Table 1.

The Cross-Cultural Assessment Tool consists of a questionnaire that measures troops' intercultural competence. Questions include evaluations of mission-related competencies, descriptions of individual strengths and weaknesses and how they can influence mission outcomes. The questionnaire is based on the model of intercultural competence [14] that describes emotional, behavioural and cognitive aspects. This instrument can be used to evaluate long-term changes in intercultural competence among troops or military units and to identify individual intercultural 
competence gaps [23].

The Cross-Cultural Competence Inventory research instrument is specifically designed to assess cultural competence of the military personnel. Specifically, it was designed to help commanders assess the readiness of their troops to communicate effectively and appropriately with foreign citizens, troops of international forces and other individuals, agencies and organizations. The tool measures six aspects of intercultural competence: (1) willingness to participate, (2) cognitive flexibility and openness, (3) emotional regulation, (4) tolerance to uncertainty (ambiguity), (5) autonomy, and (6) ethno-cultural empathy [24].

However, a detailed search in the SAGE database found that there are general managerial articles related to the development of intercultural competence $[8 ; 10 ; 11]$; however, the methodological usage of the mentioned scales is fragmentary.

\section{Conclusions}

The importance of intercultural competence in today's global world remains high. It is manifested in the most diverse spheres of modern society and, thus, is relevant to not only social sciences but also researchers of other fields and disciplines. Analysing intercultural competencies from the perspective of management research, it is important to focus on developed and validated research instruments. One of the most reviewed and widely used scales for the evaluation and analysis of intercultural competencies in management literature are Personal Communication Worldview Scale, E-model Scale for Intercultural Effectiveness [12], Global Awareness Profile (GAPtest) and Intercultural Sensitivity Scale (ISS). When conducting management research related to intercultural competencies and looking for specialized literature for independent research, it is worth paying more attention to those scientific publications that mainly publish research results related to the presentation of intercultural competencies in management.

After analysing the situation of the application of methodological scales of intercultural competence in the military context, it can be concluded that such research is carried out; however, other information platforms or databases should be used to search for such publications. In order to justify specific and most appropriate methodological research instruments that reveal managerial opportunities for developing or realizing intercultural competence in the military context, it is necessary to analyse other scientific databases and conduct systematic analysis of scientific articles, with the focus not only on summaries, but also on presentations of research methods, descriptions of methodologies, presentations of the results as well as descriptions of scientific discussions as different authors convey information differently and do not always tend to present research instruments in the same way.

\section{References}

1. Abbe, A., Geller, D. S., Everett, S. L. (2010). Measuring cross-cultural competence in soldiers and cadets: A comparison of existing instruments (Technical Report 1276). Arlington, VA: U.S. Army Research Institute for the Behavioral and Social Sciences. (DTIC No. ADA 533441).

2. Caligiuri, P., Noe, R., Nolan, R., Ryan, A. M., \& Drasgow, F. (2011). Training, developing, and assessing crosscultural competence in military personnel (Technical Report 1284). Arlington, VA: U.S. Army Research Institute for the Behavioral and Social Sciences. (DTIC No. ADA 559500).

3. Chen, G.-M., \& Starosta, W. J. (2000). The Development and Validation of the Intercultural Sensitivity Scale. National Communication Association.

4. Corbitt, J. N. (1998). Global awareness profile. Intercultural Press.

5. Deardorff, D.K. (2011). Promoting understanding and development of intercultural dialogue and peace: A comparative analysis and global perspective of regional studies on intercultural competence. Report of the State of the Arts and Perspectives on Intercultural Competences and Skills. Paris: UNESCO

6. DeVisser, P., Sands, R. G. (2014). Integrating culture general and cross-cultural competence and communication skills: possibilities for the future of military language and culture programs. The Journal of Culture, Language, and International Security, 1(1), 34-69.

7. Dodd, C., \& Garmon, C. (1987). The Measurement of Personal Report of World View as a Cognitive Communication Variable.

8. Ghosh, A. (2013). Interpersonal Cross-Cultural Contact: Exploring the Role of Cultural Encounters as Antecedent to Cultural Competence at Workplace, Management and Labour Studies, vol. 38, 1-2: pp. 81-101.

9. Hajjar, R. M. (2013). A new angle on the US military's emphasis on developing cross-cultural competence. Managing Diversity in the Military: The Value of Inclusion in a Culture of Uniformity, p. 248-262.

10. Holmes-Eber, P.; Tarzi, E.; Maki, B. (2016). U.S. Marines'Attitudes Regarding Cross-Cultural Capabilities in Military Operations: A Research Note, Armed Forces \& Society, vol. 42, 4: pp. 741-751.

11. Jaiswal, R.K.; Dash, S.; Sharma, J.K.; Mishra, A.; Kar, S. (2015). Antecedents of Turnover Intentions of 
Officers in the Indian Military: A Conceptual Framework, Vikalpa, vol. 40, 2: pp. 145-164.

12. Kupka, B., Everett, A. M., Atkins, S. G., Mertesacker, M., Walters, L., Walters, T., Graf, A., Brooks Hill, L., Dodd, C., \& Bolten, J. (2009). The intercultural communication motivation scale: An instrument to assess motivational training needs of candidates for international assignments. Human Resource Management, 48(5), 717-744.

13. Lietuvos karinè doktrina patvirtinta Lietuvos kariuomenės vado $2016 \mathrm{~m}$. balandžio $22 \mathrm{~d}$. įsakymu Nr. V-570.

14. McCloskey, M. J., Grandjean, A., Behymer, K. J., \& Ross, K. G. (2010). Assessing the development of crosscultural competence in soldiers (Technical Report 1277). Arlington, VA: U.S. Army Research Institute for the Behavioral and Social Sciences. (DTIC No. ADA 533959).

15. Norvilienė, A. (2014). Tarpkultūrinès studentų kompetencijos ugdymo(si) veiksniai. Socialinis ugdymas, 38(2), 40-55.

16. Paurienė, G. (2011). Tarpkultūrinè kompetencija ir jos ugdymas pareigūnų rengime. Visuomenès saugumas ir viešoji tvarka, 5, 114-128.

17. Piasentin, K. A. (2013). Assessing Cross-Cultural Competence: Implications for Selection and Training in the Canadian Forces [Technical Report DRDC Toronto TR 2012-067]. Defence R\&D Canada.

18. Pittaway, L. (2008). Systematic Literature Reviews. R. Thorpe \& R. Holt (Ed.), The SAGE Dictionary of Qualitative Management Research (p. 217-218). SAGE Publications Ltd.

19. Portera, A. (2014). Intercultural Competence in education, counselling and psychotherapy. Intercultural Education, 25(2,) 157-174.

20. Prakapiené, D. (2020). Tarpkultūrinès kompetencijos igyvendinant saugumo siekius. In Saugumo iššūkiai: vadybos tobulinimas: kolektyvine monografija. Vilnius: Generolo Jono Žemaičio Lietuvos karo akademija. pp. 112-142.

21. Rasmussen, L. J., Sieck, W. R., Duran, J. L. (2016). A model of culture-general competence for education and training: Validation across services and key specialties. Yellow Springs, OH: Global Cognition. Final Report. H9821D-13-C-0025

22. Ratwani, K. L., Beaubien, J., Entin, E. B., Feyre, R. J., \& Gallus, J. A. (2014). Identifying dynamic environments for cross-cultural competencies (Technical Report 1345). Fort Belvoir, VA: U.S. Army Research Institute for the Behavioral and Social Sciences.

23. Rodman, J., Hardy, W., McClary, R. (2015). Cross-Cultural competence: Introduction and Overview of Key Concepts. White Paper, žiūrèta [2019-04-29]. Prieiga per internetą: https://combinedarmscenter.army.mil/sites/ hd/HD_Library/HD_Dashboard.aspx

24. Ross, K. G., Ross, W. A., McDonald, D. P. (2009). Cross-cultural competence in the U.S. Air Force: Roles, challenges, and skills in the contemporary operating environment (Technical Report No. 9193). Interservice/ Industry Training, Simulation, and Education Conference (I/ITSEC). 